\title{
Ozonation as polishing treatment of mature landfill leachate
}

\author{
Susana Cortez, Pilar Teixeira, Rosário Oliveira*, Manuel Mota \\ IBB - Institute for Biotechnology and Bioengineering, Centre of Biological Engineering, University of Minho, Campus de Gualtar, 4710-057 Braga, Portugal
}

\section{A R T I C L E I N F O}

\section{Article history:}

Received 9 March 2010

Received in revised form 18 June 2010

Accepted 21 June 2010

Available online 26 June 2010

\section{Keywords:}

Biodegradability

Hydrogen peroxide

Mature landfill leachate

Ozone

$\mathrm{pH}$

\begin{abstract}
A B S T R A C T
Mature landfill leachate is typically resistant to biological processes. In order to enhance the biodegradability of a pre-treated mature landfill leachate, ozonation treatments in a lab-scale column were assayed under different ozone concentrations, contact time, initial pH, and hydrogen peroxide concentrations. Degradation of the landfill leachate by ozone was favoured at higher $\mathrm{pH}$ values and with the addition of $\mathrm{H}_{2} \mathrm{O}_{2}$, both consistent with the enhanced production of the hydroxyl radical under such conditions. The highest organic reduction and biodegradability improvement was observed with the $\mathrm{O}_{3} / \mathrm{H}_{2} \mathrm{O}_{2}$ process at $600 \mathrm{mg} \mathrm{H}_{2} \mathrm{O}_{2} \mathrm{~L}^{-1}$. This system was able to remove $63 \%$ of chemical oxygen demand (COD), $53 \%$ of total organic carbon (TOC), $42 \%$ of aromatic content $\left(\mathrm{UV}_{254}\right)$ and increased the leachate 5-day biochemical oxygen demand $\left(\mathrm{BOD}_{5}\right)$ to $\mathrm{COD}$ ratio from 0.01 to 0.17 . Ozone combined with $\mathrm{H}_{2} \mathrm{O}_{2}$ contributed significantly to remove and change the recalcitrant organic matter and improved leachate biodegradability, which makes this process very attractive as pre-biological treatment.
\end{abstract}

(c) 2010 Elsevier B.V. All rights reserved.

\section{Introduction}

Sanitary landfilling is still the most used and accepted method to eliminate municipal solid wastes worldwide due to its economic advantages [1]. Given the great chemical complexity and diversity of the leachate produced, sanitary landfills have searched for innovative leachate treatment technologies, in order to avoid discharges to the environment causing negative impacts to the biota or public health [2].

Leachate generated from mature landfills (with more than 10 years) is typically characterised by high ammonium $\left(\mathrm{NH}_{4}{ }^{+}\right)$content, a low 5-day biochemical oxygen demand $\left(\mathrm{BOD}_{5}\right)$ to chemical oxygen demand (COD) ratio $\left(\mathrm{BOD}_{5} / \mathrm{COD}\right.$ generally below 0.1 ), and high fraction of refractory and large organic molecules (humic substances) [2,3]. Humic substances consist of a structure of alkyl/aromatic units, mainly cross-linked by oxygen and nitrogen groups with the major functional groups being carboxylic acid, phenolic and alcoholic hydroxyls, as well as ketone and quinone groups [4].

Since biological treatments are not effective for the removal of refractory compounds and physico-chemical processes such as reverse osmosis and adsorption are non-destructive, innovative technologies have focused on advanced oxidation processes (AOPs) $[1,5]$. AOPs are attractive methods to eliminate the colour, to reduce

\footnotetext{
* Corresponding author. Tel.: +351 253604 409; fax: +351 253678986 .

E-mail addresses: susana_cortez@deb.uminho.pt (S. Cortez), pilar@deb.uminho.pt (P. Teixeira),

roliveira@deb.uminho.pt (R. Oliveira),mmota@deb.uminho.pt (M. Mota).
}

the organic load and to improve the biodegradability of recalcitrant contaminants of mature leachate [1,6,7]. These processes involve the production of powerful oxidising agents, mainly the hydroxyl radical $(\bullet \mathrm{OH})$, from single oxidants, such as ozone [8], or from a combination of strong oxidants, e.g. $\mathrm{O}_{3}$ and $\mathrm{OH}^{-}$[9], $\mathrm{H}_{2} \mathrm{O}_{2}$ [10], irradiation, e.g. ultraviolet [11], ultrasound [12] or electron beam [13], and catalysts, e.g. transition metal ions or photocatalyst [14].

Molecular ozone is a strong oxidiser having high reactivity and selectivity towards organic pollutants such as humic substances [15]. The use of ozone at high $\mathrm{pH}\left(\mathrm{O}_{3} / \mathrm{OH}^{-}\right)$or in combination with $\mathrm{H}_{2} \mathrm{O}_{2}\left(\mathrm{O}_{3} / \mathrm{H}_{2} \mathrm{O}_{2}\right)$, both favouring the production of hydroxyl radicals that have an oxidation potential higher than that of ozone molecule, are attractive processes to oxidise the complex leachate mixtures [16]. It is expected that the use of such processes as pre-treatment, to reduce and convert the large refractory organic molecules, found in mature leachates, into smaller more biodegradable intermediates, followed by biological oxidation of these intermediates would result in economical savings and improvement of the treatment efficiency [11,17].

The treatment of mature landfill leachate using ozone, ozone at alkaline $\mathrm{pH}$ or ozone with hydrogen peroxide has been demonstrated in the literature. For instance, Tizaoui et al. [16] reported that ozone alone ensured a COD removal of about $27 \%$ after $60 \mathrm{~min}$ of ozonation, while the $\mathrm{O}_{3}$ and $\mathrm{H}_{2} \mathrm{O}_{2}$ combination increased COD removal up to $48 \%$. Hagman et al. [2] verified the same tendency obtaining an improvement in COD reduction from $22 \%$ for ozone alone to 50\% when hydrogen peroxide was added. Goi et al. [18] studied the effect of $\mathrm{pH}$ on ozonation of a landfill leachate, achieving COD removal efficiencies of $24 \%, 29 \%$ and $41 \%$ at initial $\mathrm{pH}$ 4.5, 8.1 and 11, respectively. Many researchers $[11,16,17,19,20]$ 
Table 1

Landfill leachate characteristics.

\begin{tabular}{lc}
\hline Parameter & Value \\
$\mathrm{pH}$ & $3.5 \pm 0.1$ \\
Conductivity $\left(\mathrm{mS} \mathrm{cm}^{-1}\right)$ & $4.45 \pm 0.03$ \\
$\mathrm{COD}\left(\mathrm{mg} \mathrm{L}^{-1}\right)$ & $743 \pm 14$ \\
$\mathrm{BOD}\left(\mathrm{mg} \mathrm{L}^{-1}\right)$ & $10 \pm 1$ \\
$\mathrm{TOC}\left(\mathrm{mg} \mathrm{L}^{-1}\right)$ & $284 \pm 6$ \\
$\mathrm{UV}$ & 254 \\
$\mathrm{~N}_{25} \mathrm{NO}_{3}^{-}\left(\mathrm{mg} \mathrm{L}^{-1}\right)$ & $2.614 \pm 0.023$ \\
$\mathrm{~N}-\mathrm{NO}_{2}^{-}\left(\mathrm{mg} \mathrm{L}^{-1}\right)$ & $1824 \pm 103$ \\
$\mathrm{~N}-\mathrm{NH}_{4}^{+}\left(\mathrm{mg} \mathrm{L}^{-1}\right)$ & $<0.01$ \\
$\mathrm{VSS}\left(\mathrm{mg} \mathrm{L}^{-1}\right)$ & $714 \pm 23$ \\
\hline
\end{tabular}

observed a significant enhancement in biodegradability, defined as the $\mathrm{BOD}_{5} / \mathrm{COD}$ ratio, after ozonation. However, none of these reports evaluated the effect of different $\mathrm{O}_{3}$ concentrations, $\mathrm{O}_{3}$ at different $\mathrm{pH}$ values and $\mathrm{O}_{3}$ with different $\mathrm{H}_{2} \mathrm{O}_{2}$ concentrations on leachate $\mathrm{COD}, \mathrm{BOD}_{5}, \mathrm{pH}$, ultraviolet absorbance at $254 \mathrm{~nm}\left(\mathrm{UV}_{254}\right)$ and nitrogenous compounds.

Therefore, the objective of this study was to investigate the ozonation of a mature landfill leachate, in order to transform refractory compounds and improve leachate biodegradability. Experiments were conducted at different ozone concentrations, contact time, initial $\mathrm{pH}$ and $\mathrm{H}_{2} \mathrm{O}_{2}$ concentrations in a lab-scale column. The leachate under study had already been treated in the treatment plant of the sanitary landfill, which comprises stabilisation, anaerobic ponds, an anoxic tank, aerated ponds and a biological decantation unit, together with an oxidation tank and two chemical precipitators. In spite of that, at the end of the process the leachate still did not meet the maximum allowable nitrogen and organic matter concentrations for direct or indirect discharge. In previous studies, we developed a biological process using an anoxic rotating biological contactor to remove nitrate. Despite its high efficiency in nitrate removal, it was not able to remove any of the refractory organic compounds still present, and an external carbon source had to be added, which represents an additional cost.

\section{Materials and methods}

\subsection{Landfill leachate}

The landfill leachate was collected from a municipal landfill in the North of Portugal before being discharged to the municipal sewer. This landfill has been in operation since 1998. The collected leachate was stored in closed containers at $4{ }^{\circ} \mathrm{C}$ until use. The characteristics of the leachate used in the investigated period are listed in Table 1 . Taking into account the extremely low value of the $\mathrm{BOD}_{5} / \mathrm{COD}$ ratio $(0.01)$ and the high content of nitrogenammonium $\left(\mathrm{N}-\mathrm{NH}_{4}{ }^{+}\right)$, this leachate can be considered mature and rich in refractory compounds. Another important feature of this leachate is the high nitrogen-nitrate $\left(\mathrm{N}^{-} \mathrm{NO}_{3}{ }^{-}\right)$content.

\subsection{Ozonation}

The ozonation experiments were conducted in an acrylic column, semi-batch reactor, with a height of $69.5 \mathrm{~cm}$ and an internal diameter of $8.2 \mathrm{~cm}$. Ozone was produced from pure and dry oxygen by corona discharge using an ozone generator (Anseros Peripheral Com-AD-02), capable of producing up to $8 \mathrm{~g} \mathrm{O}_{3} \mathrm{~h}^{-1}$. The ozone and oxygen mixture was continuously introduced into the column through a ceramic diffuser placed at the bottom and was allowed to react with each sample for $60 \mathrm{~min}$. The inlet and outlet concentrations of ozone in the gas phase were measured at $254 \mathrm{~nm}$ using an ozone analyser (Anseros Ozomat GM-6000-OEM), throughout the experiments. The residual gas was vented through the catalytic ozone destruction unit. A needle valve and a gas flow meter were placed before the column to control and measure the ozone and oxygen mixture flow rate in $\mathrm{Lh}^{-1}$. For every experiment the reactor was filled with one litre of leachate. Effluent samples were taken during reaction at the bottom of the column.

The effect of initial $\mathrm{pH}$ was studied adjusting the $\mathrm{pH}$ of the leachate with $\mathrm{NaOH}$. In $\mathrm{O}_{3} / \mathrm{H}_{2} \mathrm{O}_{2}$ experiments, the required amount of $\mathrm{H}_{2} \mathrm{O}_{2}$ was injected in a single-step to the column at time zero. The samples collected from these trials were treated with a saturated solution of $\mathrm{NaOH}$ to quench the reaction of residual $\mathrm{H}_{2} \mathrm{O}_{2}$.

All experiments were carried out at room temperature $\left(20 \pm 2^{\circ} \mathrm{C}\right)$, performed in duplicate and the results were averaged.

\subsection{Analytical methods}

The leachate was characterised before and after ozonation, through analyses of $\mathrm{pH}$, chemical oxygen demand (COD), total organic carbon (TOC), 5-day biochemical oxygen demand $\left(\mathrm{BOD}_{5}\right)$, nitrogen-nitrate $\left(\mathrm{N}-\mathrm{NO}_{3}{ }^{-}\right)$, nitrogen-nitrite $\left(\mathrm{N}-\mathrm{NO}_{2}{ }^{-}\right)$, nitrogenammonium $\left(\mathrm{N}-\mathrm{NH}_{4}{ }^{+}\right)$, and $\mathrm{UV}$ absorbance at $254 \mathrm{~nm}$. COD, $\mathrm{BOD}_{5}$, $\mathrm{N}-\mathrm{NO}_{2}{ }^{-}$, and $\mathrm{N}-\mathrm{NH}_{4}{ }^{+}$concentrations were determined according to standard methods [21]. Nitrate concentration was measured by high-performance liquid chromatography (HPLC), using a Varian Metacarb column (type 67H, $9 \mu \mathrm{m}, 300 \mathrm{~mm}$ long, $6.5 \mathrm{~mm}$ internal diameter) and a mobile phase of $0.005 \mathrm{M}$ sulphuric acid $\left(\mathrm{H}_{2} \mathrm{SO}_{4}\right)$ at $0.7 \mathrm{~mL} \mathrm{~min}^{-1}$. Column temperature was set at $60^{\circ} \mathrm{C}$ and nitrate was detected by UV at $210 \mathrm{~nm}$. Ultraviolet absorbance at $254 \mathrm{~nm}$ $\left(\mathrm{UV}_{254}\right)$ was monitored with a Jasco V-560 spectrophotometer. TOC measurements were performed using a Dohrmann DC-190 TOC Analyser.

\section{Results and discussion}

\subsection{Effect of inlet ozone concentration and contact time}

The effect of inlet ozone concentration was investigated at 63 , 74 and $112 \mathrm{mg} \mathrm{L}^{-1} \mathrm{NTP}$, corresponding to a gas flow rate of 2.5, 1.67 and $0.83 \mathrm{~L} \mathrm{~min}^{-1}$, respectively. These experiments were carried out at the natural $\mathrm{pH}$ of the landfill leachate ( $\mathrm{pH} 3.5$ ). Table 2 presents the results of ozone consumption, COD, TOC, and $\mathrm{UV}_{254}$ removal efficiencies, as well as $\mathrm{N}-\mathrm{NO}_{2}{ }^{-}, \mathrm{N}-\mathrm{NO}_{3}{ }^{-}$and $\mathrm{N}_{-} \mathrm{NH}_{4}{ }^{+}$variations throughout time at different $\mathrm{O}_{3}$ concentrations. Ozone consumption (OC) was calculated according to Eq. (1):

$\mathrm{OC}\left(\mathrm{g} \mathrm{O}_{3} \mathrm{~L}^{-1}\right.$ liquid $)=\frac{\mathrm{Q}_{\mathrm{G}}}{V_{\mathrm{L}}} \int_{0}^{t}\left(\left[\mathrm{O}_{3 \mathrm{G}, \mathrm{i}}\right]-\left[\mathrm{O}_{3 \mathrm{G}, \mathrm{o}}\right]\right) d t$

where $Q_{\mathrm{G}}$ is the gas flow rate $\left(\mathrm{L} \mathrm{min}^{-1}\right), V_{\mathrm{L}}$ the liquid volume (L), and $\left[\mathrm{O}_{3 \mathrm{G}, \mathrm{i}}\right]$ and $\left[\mathrm{O}_{3 \mathrm{G}, \mathrm{o}}\right]$ are the ozone concentrations $\left(\mathrm{g} \mathrm{L}^{-1} \mathrm{NTP}\right)$ in the gas stream at the inlet and outlet, respectively. The inlet ozone concentration remained constant over time for each experiment.

It was observed that COD and TOC removal efficiencies increased with contact time and ozone concentration. The highest ozone consumption was observed for the highest ozone concentration tested, suggesting a more effective use of the ozone supplied to the system. This fact is due to the higher ozone partial pressure that provides higher solubility of ozone, achieving maximum ozone mass transfer and consequent availability.

It is difficult to compare the removal efficiency values obtained herein with the ones presented in the literature because these depend on many factors (the type of reactor, $\mathrm{pH}$, temperature etc.). Furthermore, the landfill leachate used in this study had the particularity of having been previously treated.

COD removal efficiency increased faster initially levelling off after $30 \mathrm{~min}$ (Table 2 ). The COD degradation was rapid during the initial period probably due to the availability of easily oxidisable compounds, such as phenols, quinones and aromatic acids. Further 
Table 2

Effect of ozone concentration and contact time on OC, COD, TOC and $\mathrm{UV}_{254}$ removal efficiencies; $\mathrm{N}^{-} \mathrm{NO}_{2}{ }^{-}, \mathrm{N}^{-} \mathrm{NO}_{3}{ }^{-}$and N-NH${ }_{4}^{+}$concentrations.

\begin{tabular}{|c|c|c|c|c|c|c|c|}
\hline \multirow{2}{*}{$\begin{array}{l}\mathrm{O}_{3} \text { concentration } \\
\left(\mathrm{mg} \mathrm{L}^{-1} \mathrm{NTP}\right)\end{array}$} & \multirow[t]{2}{*}{ Parameter } & \multicolumn{6}{|c|}{ Contact time (min) } \\
\hline & & 0 & 5 & 15 & 30 & 45 & 60 \\
\hline \multirow{7}{*}{63} & $\mathrm{OC}\left(\mathrm{g} \mathrm{O}_{3} \mathrm{~L}^{-1}\right.$ effluent $)$ & & 0.44 & 1.25 & 2.19 & 3.01 & 3.89 \\
\hline & COD removal (\%) & & 4 & 6 & 7 & 10 & 10 \\
\hline & TOC removal (\%) & & 2 & 4 & 5 & 6 & 7 \\
\hline & $\mathrm{UV}_{254}$ removal (\%) & & 10 & 14 & 16 & 18 & 19 \\
\hline & $\mathrm{N}-\mathrm{NO}_{2}{ }^{-}\left(\mathrm{mg} \mathrm{L}^{-1}\right)$ & 0.01 & 0.04 & 0.04 & 0.03 & 0.03 & 0.03 \\
\hline & $\mathrm{N}-\mathrm{NO}_{3}-\left(\mathrm{mg} \mathrm{L}^{-1}\right)$ & 2045 & 2078 & 2088 & 2109 & 2106 & 2096 \\
\hline & $\mathrm{N}-\mathrm{NH}_{4}{ }^{+}\left(\mathrm{mg} \mathrm{L}^{-1}\right)$ & 690 & 675 & 659 & 637 & 622 & 650 \\
\hline \multirow{7}{*}{74} & $\mathrm{OC}\left(\mathrm{g} \mathrm{O}_{3} \mathrm{~L}^{-1}\right.$ effluent $)$ & & 0.55 & 1.39 & 2.35 & 3.24 & 4.07 \\
\hline & COD removal (\%) & & 6 & 10 & 14 & 16 & 17 \\
\hline & TOC removal (\%) & & 3 & 8 & 9 & 11 & 11 \\
\hline & $\mathrm{UV}_{254}$ removal (\%) & & 9 & 15 & 18 & 19 & 21 \\
\hline & $\mathrm{N}-\mathrm{NO}_{2}{ }^{-}\left(\mathrm{mg} \mathrm{L}^{-1}\right)$ & 0.01 & 0.03 & 0.03 & 0.03 & 0.03 & 0.03 \\
\hline & $\mathrm{N}-\mathrm{NO}_{3}-\left(\mathrm{mg} \mathrm{L}^{-1}\right)$ & 2089 & 2100 & 2129 & 2152 & 2157 & 2162 \\
\hline & $\mathrm{N}-\mathrm{NH}_{4}{ }^{+}\left(\mathrm{mg} \mathrm{L}^{-1}\right)$ & 767 & 764 & 746 & 725 & 711 & 699 \\
\hline \multirow{7}{*}{112} & $\mathrm{OC}\left(\mathrm{g} \mathrm{O}_{3} \mathrm{~L}^{-1}\right.$ effluent $)$ & & 0.61 & 1.42 & 2.40 & 3.37 & 4.38 \\
\hline & COD removal (\%) & & 10 & 13 & 17 & 20 & 23 \\
\hline & TOC removal (\%) & & 5 & 8 & 10 & 13 & 14 \\
\hline & $\mathrm{UV}_{254}$ removal (\%) & & 9 & 17 & 19 & 21 & 22 \\
\hline & $\mathrm{N}-\mathrm{NO}_{2}{ }^{-}\left(\mathrm{mg} \mathrm{L}^{-1}\right)$ & 0.01 & 0.03 & 0.04 & 0.03 & 0.03 & 0.03 \\
\hline & $\mathrm{N}-\mathrm{NO}_{3}-\left(\mathrm{mg} \mathrm{L}^{-1}\right)$ & 2059 & 2075 & 2123 & 2144 & 2154 & 2162 \\
\hline & $\mathrm{N}-\mathrm{NH}_{4}{ }^{+}\left(\mathrm{mg} \mathrm{L}^{-1}\right)$ & 785 & 763 & 743 & 713 & 699 & 690 \\
\hline
\end{tabular}

increase in reaction time led to a slow change in organic removal rate, indicating the formation of by-products such as aliphatic acids and aldehydes, which were difficult to further degrade $[15,16]$. A similar tendency was observed with TOC removal efficiency. Wang et al. [10] and Chaturapruek et al. [15] also reported two kinetic periods in the COD and TOC removal efficiencies of a mature landfill leachate. Therefore, it is not always worthwhile to increase the ozone contact time.

The degree of carbon mineralisation (TOC removal) was lower than COD removal throughout the study. This phenomenon is probably related with the generation and accumulation of carboxylic acids and aldehydes as final products, rather than $\mathrm{CO}_{2}[11,19]$.

The molecular ozone is very effective in the oxidation of aromatic compounds susceptible to electrophilic attack. Thus, ozonation can easily alter the molecular structure of the leachate organics from aromatic and unsaturated constituents to saturated intermediates [17,22]. The absorbance at $254 \mathrm{~nm}\left(\mathrm{UV}_{254}\right)$ has been reported to be a qualitative indicator of aromatic and unsaturated compounds present in wastewater [17,23]. From Table 2 it can be observed that $\mathrm{UV}_{254}$ removal efficiency increased with contact time and slightly improved with the increase of inlet ozone concentration. A rapid increase of the $U_{254}$ removal efficiency was noted during the first $30 \mathrm{~min}$, but the oxidation rate decreased as the reaction proceeded. $U_{254}$ removal was, in general, higher than COD and TOC removal efficiencies. These results support the hypothesis that molecular ozone reacted promptly with aromatic and unsaturated compounds inducing the decrease of aromaticity, but generated compounds that react more slowly and are resistant to further oxidation such as carboxylic acids and aldehydes instead of $\mathrm{CO}_{2}$, as mentioned above.

Mature landfill leachate typically presents high concentrations of nitrogenous pollutants. During these experiments only about $10 \%$ of nitrogen-ammonium was converted to nitrogen-nitrate due to the acidic conditions assayed ( $\mathrm{pH}$ 3.5). In fact, previous studies $[24,25]$ showed that this oxidation is negligible in acidic solutions because at $\mathrm{pH}$ lower than 7 , ammonia $\left(\mathrm{NH}_{3}\right)$ exists in the aqueous solution essentially in its ionised form $\left(\mathrm{NH}_{4}{ }^{+}\right)$, which is not reactive toward ozone. Nevertheless, it should also be noted that species such as bromide are known to favour ammonia removal [24].

Once ammonium removal consumes ozone, it would be interesting to determine whether or not $\mathrm{N}_{-} \mathrm{NH}_{4}{ }^{+}$should be removed before oxidation, by a biological nitrification process or by air stripping.

A slight decrease in $\mathrm{pH}$ from 3.5 to 3.0 was observed in these experiments (data not shown).

The biodegradability of an effluent can be described in terms of $\mathrm{BOD}_{5} / \mathrm{COD}$ ratio. In order to assess the effect of different ozone concentrations on leachate biodegradability, $\mathrm{BOD}_{5}$ measurements after 60 min of treatment were carried out and the results obtained are compiled in Fig. 1.

After ozonation, $\mathrm{BOD}_{5}$ increased by about $80 \%$ at $63 \mathrm{mg} \mathrm{O}_{3} \mathrm{~L}^{-1}$ NTP, $160 \%$ at $74 \mathrm{mg} \mathrm{O}_{3} \mathrm{~L}^{-1} \mathrm{NTP}$, and $180 \%$ at $112 \mathrm{mg} \mathrm{O}_{3} \mathrm{~L}^{-1}$ NTP. Consequently, $\mathrm{BOD}_{5} / \mathrm{COD}$ ratio increased with the increase of the ozone concentration from 0.03 at $63 \mathrm{mg} \mathrm{O}_{3} \mathrm{~L}^{-1}$ NTP to 0.06 at $112 \mathrm{mg} \mathrm{O}_{3} \mathrm{~L}^{-1} \mathrm{NTP}$.

According to the results, a gas flow rate of $0.83 \mathrm{Lmin}^{-1}$ and an inlet ozone concentration of about $112 \mathrm{mg} \mathrm{L}^{-1} \mathrm{NTP}$ were chosen for further experiments.

\subsection{Effect of initial $p H$}

The effect of initial pH on ozone consumption and degradation of the landfill leachate pollutants by ozonation is given in Table 3 . OC, COD and TOC removal efficiencies increased as the $\mathrm{pH}$ raised because under basic $\mathrm{pH}$ higher number of ozone molecules are decomposed to generate $\mathrm{OH}^{-}$and $\bullet \mathrm{OH}$ radicals and a less selective

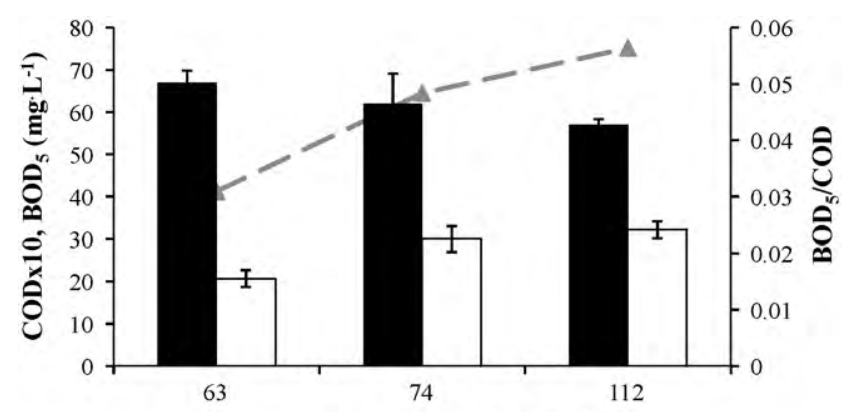

Ozone concentration $\left(\mathrm{mg} \mathrm{O}_{3} \cdot \mathrm{L}^{-1} \mathrm{NTP}\right)$

Fig. 1. Effect of ozone concentration on $\operatorname{COD}(\mathbf{\square}), \mathrm{BOD}_{5}(\square)$, and $\mathrm{BOD}_{5} / \mathrm{COD}$ ratio $(\boldsymbol{\Delta})$ after 60 min of treatment. 
Table 3

Effect of initial $\mathrm{pH}$ on OC, $\mathrm{COD}, \mathrm{TOC}$ and $\mathrm{UV}_{254}$ removal efficiencies; $\mathrm{N}-\mathrm{NO}_{2}{ }^{-}, \mathrm{N}_{-} \mathrm{NO}_{3}{ }^{-}$, and $\mathrm{N}-\mathrm{NH}_{4}{ }^{+}$concentrations after 60 min of ozonation with an ozone concentration of $112 \mathrm{mg} \mathrm{O}_{3} \mathrm{~L}^{-1} \mathrm{NTP}$.

\begin{tabular}{|c|c|c|c|c|}
\hline Parameter & $\mathrm{pH} 3.5^{\mathrm{a}}$ & $\mathrm{pH} 7$ & $\mathrm{pH} 9$ & $\mathrm{pH} 11$ \\
\hline $\mathrm{OC}\left(\mathrm{g} \mathrm{O}_{3} \mathrm{~L}^{-1}\right.$ effluent) & 4.38 & 4.89 & 5.05 & 5.14 \\
\hline COD removal (\%) & 23 & 30 & 36 & 40 \\
\hline TOC removal (\%) & 14 & 21 & 28 & 32 \\
\hline $\mathrm{UV}_{254}$ removal (\%) & 22 & 22 & 22 & 22 \\
\hline $\mathrm{N}-\mathrm{NO}_{2}-\left(\mathrm{mg} \mathrm{L}^{-1}\right)$ & 0.03 & 0.06 & 0.13 & 0.08 \\
\hline $\mathrm{N}-\mathrm{NO}_{3}{ }^{-}\left(\mathrm{mg} \mathrm{L}^{-1}\right)$ & 2162 & 2188 & 2228 & 2263 \\
\hline $\mathrm{N}-\mathrm{NH}_{4}{ }^{+}\left(\mathrm{mg} \mathrm{L}^{-1}\right)$ & 690 & 619 & 565 & 548 \\
\hline
\end{tabular}

a $\mathrm{pH} 3.5$ was the natural $\mathrm{pH}$ of the landfill leachate.

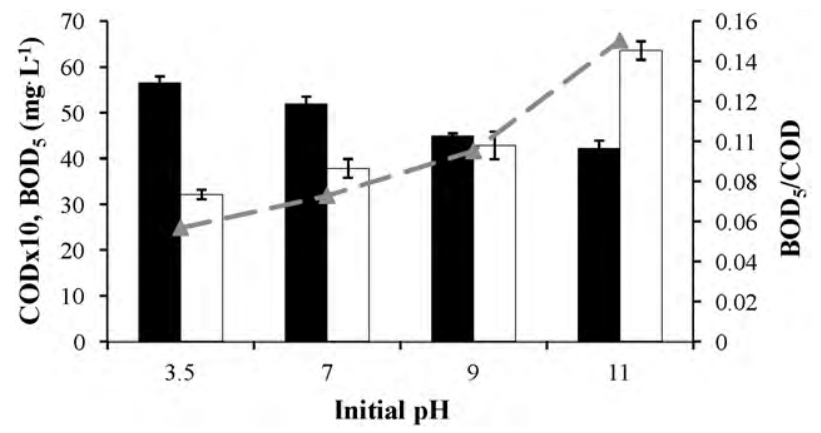

Fig. 2. Effect of initial $\mathrm{pH}$ on $\mathrm{COD}(\boldsymbol{\square}), \mathrm{BOD}_{5}(\square)$, and $\mathrm{BOD}_{5} / \mathrm{COD}$ ratio $(\boldsymbol{\Delta})$ after $60 \mathrm{~min}$ of ozonation with an ozone concentration of $112 \mathrm{mg} \mathrm{O}_{3} \mathrm{~L}^{-1}$ NTP.

and more powerful hydroxyl oxidation dominates [26,22]. $\mathrm{UV}_{254}$ removal efficiency was not affected by $\mathrm{pH}$.

The results show that ozonation at high $\mathrm{pH}$ values favoured the conversion of ammonium (in the un-ionised form) to nitrate (Table 3), as also observed by Singer and Zilli [27].

In these experiments, after $60 \mathrm{~min}$ of reaction only a slight decrease in $\mathrm{pH}$ values was noticed (data not shown). The maximum drop (2.2 units) was observed at initial $\mathrm{pH}$ 7. Probably carbonates accumulated in the treated leachate as a result of mineralisation at basic $\mathrm{pH}$, while carboxylic acids and aldehydes [10] were produced by direct ozonation reactions at $\mathrm{pH} 7$.

Fig. 2 depicts the results of $\mathrm{COD}, \mathrm{BOD}_{5}$, and $\mathrm{BOD}_{5} / \mathrm{COD}$ as a function of initial $\mathrm{pH}$, after ozonation. $\mathrm{BOD}_{5}$ increased about $180 \%$ at $\mathrm{pH}$ $3.5,230 \%$ at $\mathrm{pH} 7,275 \%$ at $\mathrm{pH} 9$ and $455 \%$ at $\mathrm{pH} 11$. The raise in $\mathrm{BOD}_{5}$ can be due to the transformation of the refractory large compounds into smaller and more biodegradable products [10].

\subsection{Effect of hydrogen peroxide concentration}

The AOP experiments associating ozone and hydrogen peroxide $\left(\mathrm{O}_{3} / \mathrm{H}_{2} \mathrm{O}_{2}\right)$ were performed with $\mathrm{H}_{2} \mathrm{O}_{2}$ at 200,400 and $600 \mathrm{mg} \mathrm{L}^{-1}$. According to Staehelin and Hoigné [28], the lower limit for the effectiveness of the $\mathrm{H}_{2} \mathrm{O}_{2} / \mathrm{O}_{3}$ process is in a $\mathrm{pH}$ range of 5-7, therefore, the $\mathrm{O}_{3} / \mathrm{H}_{2} \mathrm{O}_{2}$ process was applied to leachate, after correction to $\mathrm{pH} 7$.

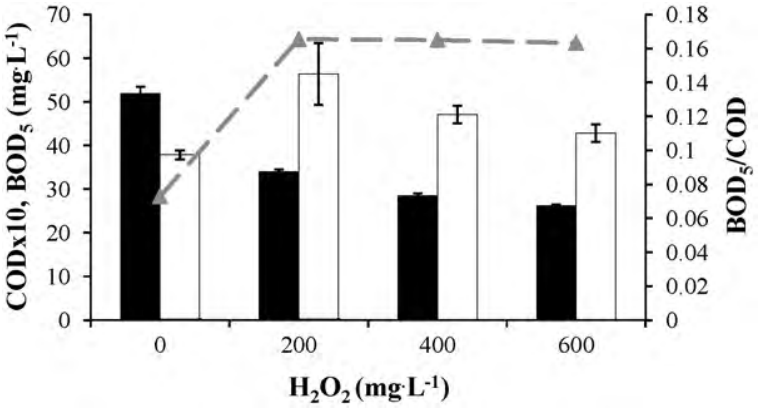

Fig. 3. Effect of hydrogen peroxide concentration on $\operatorname{COD}(\boldsymbol{\square}), \mathrm{BOD}_{5}(\square)$, and $\mathrm{BOD}_{5} / \mathrm{COD}$ ratio $(\boldsymbol{\Delta})$ after $60 \mathrm{~min}$ of ozonation with an ozone concentration of $112 \mathrm{mg} \mathrm{O}_{3} \mathrm{~L}^{-1} \mathrm{NTP}$ at $\mathrm{pH} 7$

Table 4 presents the results of ozone consumption, COD, TOC, and $U_{254}$ removal efficiencies, as well as nitrogenous compounds concentrations after ozonation at different $\mathrm{H}_{2} \mathrm{O}_{2}$ concentrations. Additionally, and as a control, landfill leachate was treated with hydrogen peroxide only at the same concentrations for $60 \mathrm{~min}$ and during the experiments no changes of parameters were detected since the hydrogen peroxide alone is not a strong oxygen transfer agent (data not shown).

The $\mathrm{O}_{3} / \mathrm{H}_{2} \mathrm{O}_{2}$ process enhanced the degradation of the landfill leachate compared to $\mathrm{O}_{3}$ only. In the $\mathrm{O}_{3} / \mathrm{H}_{2} \mathrm{O}_{2}$ system the production of hydroxyl radicals is significantly high, thus these results confirmed that the oxidation of this effluent was mainly due to these chemical species. In addition, they also promoted an increase in $\mathrm{UV}_{254}$ removal.

Some authors $[16,22,29]$ report that an increase in hydrogen peroxide concentration will not always increase organic compounds degradation. In effect, supplying hydrogen peroxide in excess will change its role from being the initiator for the production of $\bullet \mathrm{OH}$ radicals to inhibitor of ozone decomposition through free radical reactions. As a consequence, degradation of the organic matter in the leachate diminishes. In this work, since for the tested amounts of $\mathrm{H}_{2} \mathrm{O}_{2}$ the oxidation rate increased as the hydrogen peroxide concentration increased, that trend was not observed and perhaps the optimum hydrogen peroxide dose was not found.

Considering nitrogenous pollutants, as is shown in Table 4, nitrogen-ammonium was converted to nitrogen-nitrate and it was not verified a significant difference between the treatments with $\mathrm{O}_{3}$ only and $\mathrm{O}_{3} / \mathrm{H}_{2} \mathrm{O}_{2}$, for the different amounts of $\mathrm{H}_{2} \mathrm{O}_{2}$ assayed.

Results of the effect of $\mathrm{O}_{3}$ only and $\mathrm{O}_{3} / \mathrm{H}_{2} \mathrm{O}_{2}$ on biodegradability are presented in Fig. 3. Biodegradability improved in both systems; however, the $\mathrm{O}_{3} / \mathrm{H}_{2} \mathrm{O}_{2}$ process presented noticeable higher $\mathrm{BOD}_{5} / \mathrm{COD}$ values. A BOD $/$ COD ratio of about 0.17 was achieved for the different concentrations of peroxide.

A simplistic economical analysis of the operating costs associated to each AOP studied, such as expenses of reagents and energy, was performed. The calculated costs, based on $60 \mathrm{~min}$ of operating time and considering $0.09 € \mathrm{kWh}^{-1} ; 0.35 € \mathrm{~kg}^{-1} \mathrm{NaOH}, 0.33 € \mathrm{~L}^{-1}$ $\mathrm{H}_{2} \mathrm{O}_{2}(35 \%)$ and $0.08 € \mathrm{~m}^{-3} \mathrm{O}_{2}$, are summarised in Table 5.

Table 4

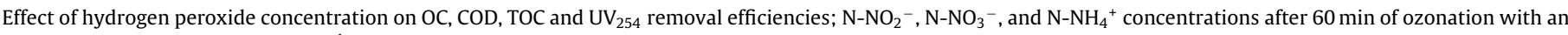
ozone concentration of $112 \mathrm{mg} \mathrm{O}_{3} \mathrm{~L}^{-1} \mathrm{NTP}$ at $\mathrm{pH} 7$.

\begin{tabular}{|c|c|c|c|c|}
\hline Parameter & $0 \mathrm{mg} \mathrm{H}_{2} \mathrm{O}_{2} \mathrm{~L}^{-1}$ & $200 \mathrm{mg} \mathrm{H}_{2} \mathrm{O}_{2} \mathrm{~L}^{-1}$ & $400 \mathrm{mg} \mathrm{H}_{2} \mathrm{O}_{2} \mathrm{~L}^{-1}$ & $600 \mathrm{mg} \mathrm{H}_{2} \mathrm{O}_{2} \mathrm{~L}^{-1}$ \\
\hline $\mathrm{OC}\left(\mathrm{g} \mathrm{O}_{3} \mathrm{~L}^{-1}\right.$ effluent) & 4.89 & 5.19 & 5.30 & 5.40 \\
\hline COD removal (\%) & 30 & 47 & 57 & 63 \\
\hline TOC removal (\%) & 21 & 38 & 50 & 53 \\
\hline $\mathrm{UV}_{254}$ removal (\%) & 22 & 30 & 36 & 42 \\
\hline $\mathrm{N}-\mathrm{NO}_{2}{ }^{-}\left(\mathrm{mg} \mathrm{L}^{-1}\right)$ & 0.06 & 0.08 & 0.14 & 0.12 \\
\hline $\mathrm{N}-\mathrm{NO}_{3}^{-}\left(\mathrm{mg} \mathrm{L}^{-1}\right)$ & 2188 & 2191 & 2171 & 2166 \\
\hline $\mathrm{N}-\mathrm{NH}_{4}{ }^{+}\left(\mathrm{mg} \mathrm{L}^{-1}\right)$ & 619 & 621 & 632 & 632 \\
\hline
\end{tabular}


Table 5

Operating costs for the AOPs studied.

\begin{tabular}{ll}
\hline AOP & Operating costs $\left(€ \mathrm{~m}^{-3} \mathrm{~g}^{-1}\right.$ of COD removed $)$ \\
\hline $\mathrm{O}_{3} / \mathrm{pH} \mathrm{3.5}$ & 64.0 \\
$\mathrm{O}_{3} / \mathrm{pH} 7$ & 49.4 \\
$\mathrm{O}_{3} / \mathrm{pH} 9$ & 41.7 \\
$\mathrm{O}_{3} / \mathrm{pH} 11$ & 38.2 \\
$\mathrm{O}_{3} / 200 \mathrm{mg} \mathrm{H}_{2} \mathrm{O}_{2} \mathrm{~L}^{-1}$ & 31.9 \\
$\mathrm{O}_{3} / 400 \mathrm{mg} \mathrm{H}_{2} \mathrm{O}_{2} \mathrm{~L}^{-1}$ & 26.6 \\
$\mathrm{O}_{3} / 600 \mathrm{mg} \mathrm{H}_{2} \mathrm{O}_{2} \mathrm{~L}^{-1}$ & 24.7 \\
\hline
\end{tabular}

a $\mathrm{pH} 3.5$ was the natural $\mathrm{pH}$ of the landfill leachate.

The lowest operating cost was $24.7 € \mathrm{~m}^{-3} \mathrm{~g}^{-1}$ of COD removed for the experiment carried out with the $\mathrm{O}_{3} / \mathrm{H}_{2} \mathrm{O}_{2}$ system at $600 \mathrm{mg} \mathrm{H}_{2} \mathrm{O}_{2} \mathrm{~L}^{-1}$. Considering the operating costs of $\mathrm{O}_{3}$ alone, significant reductions in the treatment costs were obtained under basic $\mathrm{pH}$ and with hydrogen peroxide. It is important to note that a fine tuning of the operating conditions could considerably change the operating costs obtained for each treatment process.

Though there was a significant improvement in biodegradability, a $\mathrm{BOD}_{5} / \mathrm{COD}$ ratio higher than 0.4 , which is the minimum value considered appropriate for the efficient application of a biological treatment [30] was never achieved, for all processes tested, emphasising the highly recalcitrant properties of the landfill leachate studied.

Probably coupling one of $\mathrm{O}_{3} / \mathrm{H}_{2} \mathrm{O}_{2}$ conditions tested with other physico-chemical treatment process would ensure a $\mathrm{BOD}_{5} / \mathrm{COD}$ ratio higher than 0.4 before the biological treatment, without increasing significantly the operation costs. For instance, in the treatment of a landfill leachate, Monje-Ramirez and Velásquez [19] and Bila et al. [20] also applied ozonation preceded by the coagulation/flocculation of colloids and found significant biodegradability improvement.

\section{Conclusions}

In the polishing treatment of a mature landfill leachate, the combined effect of ozone with hydrogen peroxide induced higher COD and TOC removal efficiencies as well as higher leachate biodegradability, comparatively to ozone alone at natural $\mathrm{pH}$. These results are related with the enhanced production of hydroxyl radicals in the presence of $\mathrm{H}_{2} \mathrm{O}_{2}$. For comparison purposes only, estimates of operating costs were calculated. It was found that $\mathrm{O}_{3} / \mathrm{H}_{2} \mathrm{O}_{2}$ at $600 \mathrm{mg} \mathrm{H}_{2} \mathrm{O}_{2} \mathrm{~L}^{-1}$ was the most economical process $\left(24.7 € \mathrm{~m}^{-3} \mathrm{~g}^{-1}\right.$ of COD removed) to treat the leachate tested.

Since before being discharged the leachate must be denitrified, which demands the presence of a carbon source, future studies are planned to optimise the $\mathrm{O}_{3} / \mathrm{H}_{2} \mathrm{O}_{2}$ system in order to obtain even more biodegradable compounds, which could be used in the biological process.

\section{Acknowledgements}

Susana Cortez and Pilar Teixeira fully acknowledge the financial support provided from Fundação para a Ciência e Tecnologia (FCT) through the grants SFRH/BD/24715/2005 and SFRH/BPD/26803/2006, respectively.

\section{References}

[1] S. Renou, J. Givaudan, S. Poulain, F. Dirassouyan, P. Moulin, Landfill leachate treatment: review and opportunity, J. Hazard. Mater. 150 (2008) 468-493.
[2] M. Hagman, E. Heander, J.L.C. Jansen, Advanced oxidation of refractory organics in leachate-potential methods and evaluation of biodegradability of the remaining substrate, Environ. Technol. 29 (2008) 941-946.

[3] T.A. Kurniawan, W.H. Lo, G.Y. Chan, Physico-chemical treatments for removal of recalcitrant contaminants from landfill leachate, J. Hazard. Mater. 129 (2006) 80-100.

[4] H.R. Schulten, B. Plage, M. Schnitzer, A chemical-structure for humic substances, Naturwissenschaften 78 (1991) 311-312.

[5] D. Geenens, B. Bixio, C. Thoeye, Combined ozone-activated sludge treatment of landfill leachate, Water Sci. Technol. 44 (2001) 359-365.

[6] J.L. de Morais, P.P. Zamora, Use of advanced oxidation processes to improve the biodegradability of mature landfill leachates, J. Hazard. Mater. 123 (2005) 181-186.

[7] J. Kochany, E. Lipczynska-Kochany, Utilization of landfill leachate parameters for pre-treatment by Fenton reaction and struvite precipitation-a comparative study, J. Hazard. Mater. 166 (2009) 248-254.

[8] C. Di Iaconi, R. Ramadori, A. Lopez, Combined biological and chemical degradation for treating a mature municipal landfill leachate, Biochem. Eng. J. 31 (2006) $118-124$.

[9] P. Haapea, S. Korhonen, T. Tuhkanen, Treatment of industrial landfill leachates by chemical and biological methods: ozonation, ozonation hydrogen peroxide, hydrogen peroxide and biological post-treatment for ozonated water, Ozone Sci. Eng. 24 (2002) 369-378.

[10] F. Wang, M.G. El-Din, D.W. Smith, Oxidation of aged raw landfill leachate with $\mathrm{O}_{3}$ only and $\mathrm{O}_{3} / \mathrm{H}_{2} \mathrm{O}_{2}$ : treatment efficiency and molecular size distribution analysis, Ozone Sci. Eng. 26 (2004) 287-298.

[11] J.J. Wu, C.C. Wu, H.W. Ma, C.C. Chang, Treatment of landfill leachate by ozonebased advanced oxidation processes, Chemosphere 54 (2004) 997-1003.

[12] S. Wang, X. Wu, Y. Wang, Q. Li, M. Tao, Removal of organic matter and ammonia nitrogen from landfill leachate by ultrasound, Ultrason. Sonochem. 15 (2008) 933-937.

[13] B. Bae, E. Jung, Y. Kim, H. Shin, Treatment of landfill leachate using activated sludge process and electron-beam radiation, Water Res. 33 (1999) 2669-2673.

[14] S.P. Cho, S.C. Hong, S. Hong, Study of the end point of photocatalytic degradation of landfill leachate containing refractory matter, Chem. Eng. J. 98 (2004) 245-253.

[15] A. Chaturapruek, C. Visvanathan, K.H. Ahn, Ozonation of membrane bioreactor effluent for landfill leachate treatment, Environ. Technol. 26 (2005) 65-73.

[16] C. Tizaoui, L. Bouselmi, L. Mansouri, A. Ghrabi, Landfill leachate treatment with ozone and ozone/hydrogen peroxide systems, J. Hazard. Mater. 140 (2007) 316-324.

[17] A. Imai, K. Onuma, Y. Inamori, R. Sudo, Effects of pre-ozonation in refractory leachate treatment by the biological activated carbon fluidized bed process, Environ. Technol. 19 (1998) 213-221.

[18] A. Goi, Y. Veressinina, M. Trapido, Combination of ozonation and the Fenton processes for landfill leachate treatment: evaluation of treatment efficiency, Ozone Sci. Eng. 31 (2009) 28-36.

[19] I. Monje-Ramirez, M.T.O.D. Velásquez, Removal and transformation of recalcitrant organic matter from stabilized saline landfill leachates by coagulation-ozonation coupling processes, Water Res. 38 (2004) 2359-2367.

[20] D.M. Bila, A. Filipe Montalvao, A.C. Silva, M. Dezotti, Ozonation of a landfill leachate: evaluation of toxicity removal and biodegradability improvement, J. Hazard. Mater. 117 (2005) 235-242.

[21] APHA, AWWA, WPCF, Standard Methods for the Examination of Water and Wastewater, seventeenth ed., American Public Health Association, American Water Works Association, Water Pollution Control Federation, Washington, DC, 1989.

[22] A.Y. Lin, C. Lin, J. Chiou, P.A. Hong, $\mathrm{O}_{3}$ and $\mathrm{O}_{3} / \mathrm{H}_{2} \mathrm{O}_{2}$ treatment of sulfonamide and macrolide antibiotics in wastewater, J. Hazard. Mater. 171 (2009) 452-458.

[23] M.F. Sevimli, Post-treatment of pulp and paper industry wastewater by advanced oxidation processes, Ozone Sci. Eng. 27 (2005) 37-43.

[24] J. Tanaka, M. Matsumura, Application of ozone treatment for ammonia removal in spent brine, Adv. Environ. Res. 7 (2003) 835-845.

[25] S.H. Lin, C.L. Wu, Removal of nitrogenous compounds from aqueous solution by ozonation and ion exchange, Water Res. 30 (1996) 1851-1857.

[26] C.A. Somensi, E.L. Simionatto, S.L. Bertoli, A. Wisniewski Jr., C.M. Radetski, Use of ozone in a pilot-scale plant for textile wastewater pre-treatment: physicochemical efficiency, degradation by-products identification and environmental toxicity of treated wastewater, J. Hazard. Mater. 175 (2010) 235-240.

[27] P.C. Singer, W.B.Zilli, Ozonation of ammonia in wastewater, Water Res. 9(1975) $127-134$.

[28] J. Staehelin, J. Hoigné, Decomposition of ozone in water: rate of initiation by hydroxide ions and hydrogen peroxide, Environ. Sci. Technol. 16 (1982) $676-681$.

[29] I. Akmehmet Balcloglu, M. Ötker, Treatment of pharmaceutical wastewater containing antibiotics by $\mathrm{O}_{3}$ and $\mathrm{O}_{3} / \mathrm{H}_{2} \mathrm{O}_{2}$ processes, Chemosphere 50 (2003) 85-95.

[30] G. Tchobanoglous, F. Burton, Wastewater Engineering: Treatment, Disposal and Reuse, third ed., Metcalf and Eddy, Inc., McGraw-Hill Inc., New York, 1991. 